\title{
Business Communication in the Context of Improving the Personnel Policy of a Modern Organization
}

\author{
Oleksandr Temchenko ${ }^{l}$, Nataliia Shevchuk ${ }^{2 *}$, Volodymyr Musienko ${ }^{l}$, Nataliia Borodina ${ }^{3}$ and Oleksandr Drachuk ${ }^{l}$ \\ ${ }^{1}$ State University of economics and technology, Kryvyi Rih, Ukraine \\ ${ }^{2}$ National Technical University of Ukraine "Igor Sikorsky Kyiv Polytechnic Institute", Kyiv, Ukraine \\ ${ }^{3}$ Bilotserkivsky Institute of Continuous Professional Education, Bila Tserkva, Ukraine
}

\begin{abstract}
The article considers a comprehensive study of priority areas of staff motivation. Based on the systematic approach the practical ways of implementation a motivational mechanism as a key component of improving personnel policy in a banking institution were developed. The role and organization of the motivational mechanism and stimulation of labor activity in the personnel management system in the modern organization were covered. The existing methods, techniques and indicators for assessing the personnel motivation systems taking into account the financial stability of the banking institution were analyzed. Improved systems of work motivation in a modern domestic bank were proposed taking into account the monitoring and forecast of indicators of its financial and economic condition. Motivational approaches were evaluated based on the development of an effective system of material incentives and compensation (intangible) staff package in order to increase the interest of employees in obtaining the maximum result of activities in the studied bank. A comprehensive program of organizational, economic and managerial measures to improve the system of socio-economic motivation of staff in the bank was formed in accordance with the strategic guidelines of the institution.
\end{abstract}

\section{Introduction}

In a socially oriented market management system the problem of work motivation systems development becomes important. Implementation of the domestic economy development innovative model requires the creation at the state level of appropriate systemic conditions for progressive motivation and stimulation of staff work. Business communication helps very good in establishing a motivational system. Communication is a global motivating system that helps to strengthen such motives as: recognition of merits, striving for achievement, self-improvement.

The purpose of the work is a comprehensive review of business communication with coverage of personnel policy and identification of staff motivation priority areas in a modern organization, review of basic methodological approaches and practical ways of motivational mechanism development based on the study in a banking institution.

To this goal achieving the following tasks were solved:

- to investigate the role and organization of the motivational mechanism and stimulation of the staff labor activity in the context of personnel policy management in a modern banking institution;

- to analyze the existing methods, techniques and indicators of assessing the use of monetary and intangible staff motivation in banking institutions;

- consider the assessment of motivational approaches based on the development of an effective system of material incentives and staff compensation package with the aim of increasing the interest of employees in obtaining the maximum activity result in the studied bank;

- to offer improved systems of labor activity motivation in a modern domestic bank, taking into account the monitoring and implementation of effective organizational and managerial measures;

- to form a comprehensive program of organizational and economic measures to improve the system of staff socio-economic motivation in the bank in accordance with the strategic guidelines for the development of the banking institution.

The following scientific research methods were used in the article: system analysis, abstraction and analogy to deepen the research methodology of the business communication formation process in a modern organization; economic and statistical (groupings, graphanalytical, correlation-regressive, main components), factor and functional analysis, classification, typology, comparative analysis - to assess the effectiveness of personnel policy and the dynamics of monetary and intangible motivation of bank staff, determining its impact on the institution final results, the effectiveness of economic incentives for staff, determining the optimal structure of the motivational mechanism; graphic - to visualize the issues considered.

The scientific novelty of the results is to develop a sound methodology for comprehensive assessment of the business communication mechanisms effectiveness and intangible incentives for bank employees that allows to

* Corresponding author: nata520522@gmail.com 
diagnose personnel policy and socio-economic staff motivation based on the results of the banking institution in today's difficult business conditions.

This paper will consider the motivation of modern banking institutions employees.

\section{Analysis of recent research and publications}

Business communications - intergroup and interpersonal communications, the specifics, structure and functions of which are determined by the scope of business relations they are used.

Business communication allows an organization to share goals with shareholders both inside and outside the organization. Also, thanks to communication, the organization can gain the loyalty of employees and customers. Thanks to an effective communication system, the organization can calm angry customers and impress new ones [16].

Many scientific publications have been devoted to the study of problems and prospects of personnel policy formation. In particular, we consider it appropriate to single out the works of Parkhimchyk E.P. [15], Adizes I. [1], Bayrachna O.K. [2], Oyvental A.V. [14], Mamotenko D. Y. [11], Hrytsai A.M. [8], Udovenko T.S. [17], Lepeyko T.I. [10], Bortnik S.M. [5], Mornell P. [12], Berkova K. [3], Delamare le Deist F [6].

Thus according to Parkhimchyk E.P., personnel policy of the organization - is formulated (orally or in writing) principles, priorities, norms, rules of work with personnel obligatory for all participants of the personnel management process aimed at achieving organization tasks and strategic goals, and are used taking into account constant changes in internal organizational conditions and requirements of the external environment [15].

To implement the management functions of planning, organization, motivation, leadership and control, it is very important to maintain communication between stakeholders of the organization. Communication helps to deal establish between different departments of the organization, so information in modern organizations should be transmitted faster than before [13].

Analyzing scientific sources, we can conclude that scientists study mainly general trends in the development of theoretical principles and methodological approaches to the efficiency of staff activity and the formation of motivational mechanisms. Moreover the problems of formation of communication and motivation management systems, including intangible, insufficient attention is paid.

Communication processes, especially business communication, are carried out with certain goals, intentions, so the parties seek to provide not just data, but, in their opinion, ready-made information, freely or involuntarily processed, composed, formulated in such a way to obtain the expected result, behavior, reaction.

The main tasks of business communications are:

- creating and maintaining an image;
- study of external influence on the activities of the entity;

- establishing relations between the entity and target audiences;

- creating a favorable socio-economic climate and a favorable environment for doing business;

- assistance to the entity of economic activity in obtaining accurate and timely information;

- search, study and discovery of new business opportunities;

- establishing communications within the organization.

Business communications of the entity of economic activity play an important role in the implementation of strategic goals of the organization. Communicating properly formulated messages of the entity to its target groups forms a favorable basis for activities in the system of economic relations, helps to gain public support to protect the interests and reputation of the entity of economic activity. In the theory and practice of energy management, monitoring and planning systems are used in Western Europe, the USA, Japan (Pooley John, 2005; Jones Phil, 2004), the purpose of the creation and operation of Monitoring and Targeting Systems, in addition to operational management of the efficiency of the use of fuel and energy resources, is also monitoring of the real results achieved in implementing energy saving projects at a certain management object [2].

\section{Theoretical and methodological bases of the banking institutions employee motivation program development}

In the economic literature, the concept of "motivation" is interpreted from the influence standpoint not only internal but also external factors in relation to man and their interaction that motivates man work to achieve personal goals and goals of the organization. According to this understanding, the purpose of motivational management is to form a set of conditions that motivate a person to take actions aimed at achieving the goal with maximum effect [4].

Methods of staff incentives can be very diverse and depend on the operation of the incentive system, the overall management system of personnel policy and the characteristics of the organization. Consider ways to improve work motivation. They are combined in several independent directions. Wages play a great role in motivating, but the constant increase in wages does not help to maintain labor activity at the appropriate level and increase productivity. To stimulate employees you can also use the system of internal benefits to the enterprise workers, intangible (non-economic) benefits and staff privileges. Equally important is the creation of a favorable social atmosphere and a variety of activities increasing the content of work, independence and responsibility of the employee stimulating his skills growth. Involving employees in the enterprise management also increases their motivation because in 
this case the problem of alienation from the organization and its leaders is solved.

JSC CB Privatbank is the largest Ukrainian universal commercial bank operating under the license of the National Bank of Ukraine № 22 dated October 5, 2011, focused on servicing individuals and corporate clients of all forms of ownership.

Table 1. Results of PrivatBank's activity for 2017-2019.

\begin{tabular}{|l|l|l|l|}
\hline Indicators & $\mathbf{2 0 1 7}$ & $\mathbf{2 0 1 8}$ & $\mathbf{2 0 1 9}$ \\
\hline $\begin{array}{l}\text { Annual financial result, } \\
\text { UAH million }\end{array}$ & -23914 & 12789 & 32609 \\
\hline Assets, UAH million & 254805 & 278048 & 309723 \\
\hline $\begin{array}{l}\text { Total equity, UAH } \\
\text { million }\end{array}$ & 24793 & 31464 & 54529 \\
\hline $\begin{array}{l}\text { Total liabilities, UAH } \\
\text { million }\end{array}$ & 230012 & 246584 & 255194 \\
\hline $\begin{array}{l}\text { Total liabilities and } \\
\text { equity, UAH mln. }\end{array}$ & 254805 & 278048 & 309723 \\
\hline $\begin{array}{l}\text { Remuneration fund, } \\
\text { UAH million }\end{array}$ & 4559 & 5729 & 7300 \\
\hline $\begin{array}{l}\text { Average number of } \\
\text { employees, persons }\end{array}$ & 22670 & 22600 & 25797 \\
\hline
\end{tabular}

Looking at the table you can see at once that starting from 2018 economic indicators are improving, especially the large increase in profits in 2019.

For a more thorough analysis maps of competitive advantages were constructed according to the Ministry of Finance [9].

The $\mathrm{x}$-axis indicates the level of credits, the y-axis indicates the size of deposits. 1 .

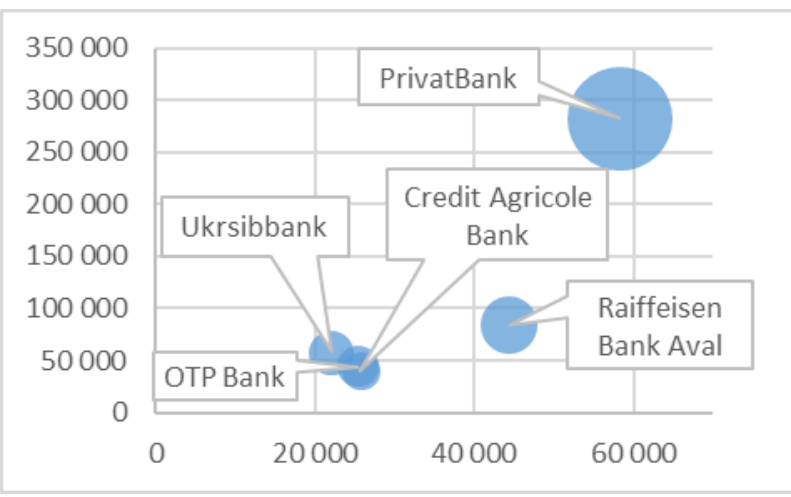

Fig 1. Map of competitive advantages by the amount of loans and deposits.

In terms of loans and deposits the closest competitor of PrivatBank is Raiffeisen Bank Aval. Less competitive there are Ukrsibbank, CrediAgricol Bank and OTP Bank that very close to each other.

In the following map of competitive advantages the $\mathrm{x}$-axis indicates the level of stress resistance; the $\mathrm{y}$-axis indicates the size of depositors loyalty.

On this map the leading banks have changed. PrivatBank has low indicators of stress resistance and depositors loyalty. The banks with the highest stress resilience and depositors loyalty are Ukrsibbank, OTP Bank and Raiffeisen Bank Aval. There are unusual indicators in CrediAgrikol Bank: stress resistance is high while depositors' loyalty is low.

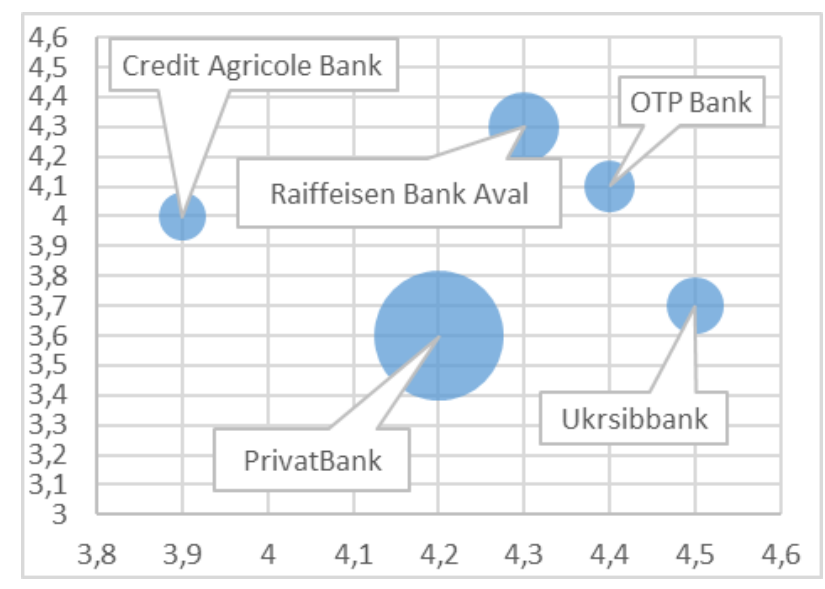

Fig. 2. Map of competitive advantages in terms of stress resistance and depositors loyalty

For a bank function well it needs a balanced personnel management system. To assess the system it is first necessary to examine the financial condition of PrivatBank, the factors influencing the bank's activities to determine competitors, strengths and weaknesses of the bank.

Table 2. Indicators of financial and economic condition of PrivatBank for 2017-2019.

\begin{tabular}{|l|l|l|l|}
\hline Indicators & 2017 & 2018 & 2019 \\
\hline Return on assets, \% & $-9,39$ & 4,60 & 10,53 \\
\hline Return on capital, \% & $-96,45$ & 40,65 & 59,80 \\
\hline Autonomy ratio & 0,097 & 0,113 & 0,176 \\
\hline Liquidity, \% & 17,26 & 17,90 & 16,21 \\
\hline Financial leverage ratio & 9,28 & 7,84 & 4,68 \\
\hline Reliability ratio & 0,11 & 0,13 & 0,21 \\
\hline $\begin{array}{l}\text { Equity participation in } \\
\text { asset formation ratio }\end{array}$ & 0,10 & 0,11 & 0,18 \\
\hline
\end{tabular}

In 2017 the bank's indicators are bad but since 2018 the indicators are improving. And in 2019 the increase in return on assets and return on capital is particularly noticeable.

Currently JSC CB "PrivatBank" uses eleven ways of intangible motivation of employees as one of the important components of personnel policy of the institution:

- motivational meetings;

- $\quad$ mreetings with significant dates;

- training: refresher courses, internships, seminars and conferences;

- the right to choose;

- possibility of feedback. It is necessary to give employees the opportunity to express themselves wishes, comments on the work organization;

- equipped places for rest. It is important for almost all employees to be able to have lunch not at the desk but in a separate room, so as not to disturb others and relax; - informing about the achievements and evaluations of employees; 
- competitions and contests;

- personal working area. It can be a sign on the door, a card on the table, a badge - these are the tools for intangible motivation of employees;

- discounts on services or products of the company;

- encouraging corporate events: a festive banquet or a trip to nature, a corporate outing to the skating rink or to the cinema (in the absence of quarantine restrictions).

Intangible motivation of PrivatBank involves the creation of an appropriate motivational climate in the team, working conditions and intangible incentives. The efficiency of intangible motivation in the team depends primarily on the leader. The working climate in the team is created by the bank's managers by:

- providing opportunities for professional and career growth; staff rotation;

- informing employees about the goals, objectives of the bank;

- the evaluation of the work of subordinates (both positive and negative);

- giving the employee the opportunity to make decisions independently within their powers;

- creating conditions for "immersion" in work;

- ensuring a favorable psychological climate in the team; open encouragement of the employee for the achieved results;

- giving the employee the opportunity to participate in the decision-making process;

- support of the initiative employees; organization of mentoring; delegation of responsibilities and powers.

Special departments (sectors) for work with personnel are engaged in development of motivational strategy of the bank. Most modern banks, namely PrivatBank, use the following methods of motivation [7]:

- remuneration system: salaries of JSC CB "PrivatBank" employees consist of rates and bonuses.

The piece-rate bonus system of payment is used;

- rating - is the final indicator characterized the efficiency of a particular employee in comparison with his colleagues within one profession;

- the social package is a set of benefits, privileges and incentives provided by the bank to its employees;

- motivational climate: in PrivatBank intangible motivation involves the creation of a motivational climate in the team, working conditions and intangible incentives;

- staff training and development: today PrivatBank has one of the most effective staff training and development systems.

The issues of staff training and development in PrivatBank are coordinated by PrivatUniversity and training centers [18]. Each training center has coaches employees of the bank who teach and transfer their experience to younger employees.

\section{Research results}

To implement the strategy of future development, five areas have been selected, in particular: to update the competitive offer, create a corporate segment, implement a cost optimization program, strengthen IT, and improve risk management.

All these innovations will make the bank more efficient and will have the following effects:

- accelerating the bank's work with customers and improving the service model;

- competitive offer will increase due to customer segmentation, organization update and remuneration;

- cost optimization by diagnosing activities and identifying potentials;

- strengthening the IT sphere, hiring professional experienced specialists and their stimulation;

- renewal of the risk management committee.

To implement all these measures an improved system of staff motivation and research into the impact of the new system on the bank's activities is needed. The system of such incentives is offered:

- raising wages is a simple and effective way;

- development of a system of career growth combined with an increase in wages, it will attract the attention of ambitious people;

- indirect financial assistance (payment for medical services, assistance with rent, etc.) that will help make work in the bank more attractive;

- holding corporate holidays will help to strength friendly relations in the team and increase employee loyalty;

- conducting training courses for employees will meet the needs of ambitious employees for self-training and improvement - a positive effect for the bank is the presence of a more qualified employee.

For the successful functioning of the motivational system it is necessary to develop communication channels so that the employee has an idea of the main aspects of the enterprise and structural units. Thus at the stage of employment a person should have information about the level of wages, career opportunities that is indirect financial assistance and opportunities for selfimprovement available in the organization. Such information will significantly increase the attractiveness of work for future and existing workers. We must also not forget that you need to constantly inform employees about the future development strategy of the enterprise. That is why it is very important to develop both internal and external sources of information to maintain the image of the organization.

One of the most important factors in the success of the organization is the involvement of employees in the strategy development and management of the organization. Each employee should have a role in the development of the organization that will greatly increase the employee's interest in the success of the company. That is why reliable communication channels are needed to disseminate all the necessary information.

Given the use of all proposals a forecast of financial and economic indicators of Privatbank for 2021 was made.

Table 3 shows that the new system of staff motivating using business communication will help PrivatBank to increase its profits in 2021 by $100.10 \%$ that is 32642 thousand hryvnias. It increase also the 
reliability and autonomy ratio, liquidity and generally the economic condition of the bank.

Table 3. Forecast of Privatbank's performance indicators taking into account the improvement of personnel policy for 2021.

\begin{tabular}{|c|c|c|c|c|}
\hline \multirow{2}{*}{ Indicators } & \multirow{2}{*}{2019} & \multirow{2}{*}{2021} & \multirow{2}{*}{$\begin{array}{l}\text { Absolute } \\
2019- \\
2021\end{array}$} & \multirow{2}{*}{$\begin{array}{l}\begin{array}{l}\text { Relative, } \\
\%\end{array} \\
2019- \\
2021 \\
\end{array}$} \\
\hline & & & & \\
\hline $\begin{array}{l}\text { Annual } \\
\text { financial } \\
\text { result, UAH } \\
\text { million. }\end{array}$ & 32609 & 65251 & 32642 & 100,1 \\
\hline $\begin{array}{l}\text { Assets, UAH } \\
\text { million. }\end{array}$ & 309723 & 456009 & 146286 & 47,23 \\
\hline $\begin{array}{l}\text { Total equity, } \\
\text { UAH million }\end{array}$ & 54529 & 88631 & 34102 & 62,54 \\
\hline $\begin{array}{l}\text { Total } \\
\text { liabilities, } \\
\text { UAH million }\end{array}$ & 255194 & 367377 & 112183 & 43,96 \\
\hline $\begin{array}{l}\text { Total } \\
\text { liabilities and } \\
\text { equity, UAH } \\
\text { mln. }\end{array}$ & 309723 & 456009 & 146286 & 47,23 \\
\hline $\begin{array}{l}\text { Remuneration } \\
\text { fund, UAH } \\
\text { million. }\end{array}$ & 7300 & 10162 & 2862 & 39,20 \\
\hline $\begin{array}{l}\text { Average } \\
\text { number of } \\
\text { employees, } \\
\text { persons }\end{array}$ & 25797 & 39601 & 13804 & 53,51 \\
\hline $\begin{array}{ll}\text { Return } & \text { on } \\
\text { assets, } \% & \end{array}$ & 10,528 & 14,309 & 3,781 & 35,91 \\
\hline $\begin{array}{ll}\begin{array}{l}\text { Return } \\
\text { capital,\% }\end{array} & \text { on } \\
\end{array}$ & 59,801 & 73,620 & 13,819 & 23,11 \\
\hline $\begin{array}{l}\text { Autonomy } \\
\text { ratio }\end{array}$ & 0,176 & 0,194 & 0,018 & 10,40 \\
\hline Liquidity,\% & 0,162 & 0,192 & 0,030 & 18,63 \\
\hline $\begin{array}{l}\text { Leverage } \\
\text { ratio }\end{array}$ & 4,680 & 4,145 & $-0,535$ & $-11,43$ \\
\hline $\begin{array}{l}\text { Reliability } \\
\text { ratio }\end{array}$ & 0,214 & 0,241 & 0,028 & 12,91 \\
\hline $\begin{array}{l}\text { Equity } \\
\text { participation } \\
\text { in asset } \\
\text { formation } \\
\text { ratio }\end{array}$ & 0,176 & 0,194 & 0,018 & 10,40 \\
\hline
\end{tabular}

In addition, the innovations will have a positive impact not only due to improved economic performance, but also due to the fact that the new personnel management system provides for the improvement of employees' skills that means that the overall professional level of the bank's employees will increase. It is also effective to increase wages through a career growth system that encourages the employee to work better and provide creative ideas to improve the bank's performance. Due to effective business communication people's interest in work will increase, due to that a significant increase in the number of employees is planned. In general we can say that due to the developed system of communications the motivation of employees increases significantly. Due to greater participation in the development of the personnel policy the attractiveness of the banking institution for new potential highly qualified professionals is growing.

\section{Conclusion}

Thus based on the conducted research of practical ways of the motivational mechanism development the necessity of reasonable stimulation of labor activity of the personnel in the system of management of modern banking institutions is proved. The existing methods and indicators of assessment of financial and economic condition and using of motivation systems by personnel in banks are analyzed. The assessment of motivational approaches based on the development of an effective system of material incentives and compensation (intangible) staff package in order to increase the interest of employees in obtaining the maximum result of activities in the studied bank is considered also.

In the context of continuing scientific research in the chosen area it is advisable to offer further study of opportunities for improvement the system of work motivation in a modern domestic bank taking into account monitoring and development of management measures based on the results of economic and mathematical modeling. This will form a comprehensive program of increasing financial stability and implementation of organizational and economic measures for business communication to improve personnel policy in difficult conditions of quarantine restrictions, in particular the system of socio-economic motivation of staff in the bank in accordance with strategic guidelines.

\section{References}

1. I. Adizes. How to overcome management crises. Diagnosis and solution of management problems. M.: BestBusinessBox, 286 p. (2007)

2. O.K. Bayrachna. Personnel policy of the organization in the system of functional training of management staff. Ukrainian Journal of Applied Economics. Volume 5. № 1. P. 342-348. (2020)

3. K.Berkova, P. Krpalek, K. Krpalkova Krelova (Czech Republic). Future specialists in economics: development of practical skills and competencies in higher education from the point of view of international employers. Economic Journal XXI 176 (3-4), 91-98. (2019)

4. N.M. Bogatska. The value of staff motivation to achieve the goals of the enterprise. Regional Economy. № 6. P. 11 - 17. (2009)

5. S.M. Bortnik. Strategic management of enterprise personnel development and modern approaches to assessing its level. Economic Journal of the Lesia Ukrainka East European National University: a journal. Lutsk: Vezha-Druk. № 2. P. 33-39. (2015) 
6. F. Delamare le Deist, J. Winterton. What is competence? International Human Resources Development, vol. 8, No. 1, 27 - 46 March. (2005)

7. O.P. Dyakiv. Internal environment of corporate social responsibility. Materials of the international scientific-practical "Imperatives and innovative mechanisms of ensuring decent work in the conditions of formation of the new economy" Kyiv: KNEU, P. 346-348. (2017)

8. A.M. Hrytsay. Theoretical and methodological principles of the enterprise personnel policy formation. Scientific Bulletin of Poltava University of Economics and Trade. № 1 (63). P. 148-155. (2014)

9. https://minfin.com.ua/banks/rating/?date=2020-1001

10. T.I. Lepeyko, O.M. Mironova. Personnel management of the enterprise in conditions of uncertainty (behavioral approach): monograph. Kharkiv: Ed. KhNEU, 236 p. (2015)

11. D. Y. Mamotenko. Development of personnel strategy of the organization in modern conditions. Scientific Bulletin of Kherson State University. №14. P. 49-52. (2015).

12. P. Mornell. Hiring efficiency technologies. New system of personnel evaluation and selection. Moscow: National Space Bank; Good book, 264 p. (2005)

13. S.Tulchynska, N. Shevchuk, V. Chornii, B. Chornii. Using a methodical approach to the evaluation of attractiveness investment resources for electricity distribution companies. Scientific Bulletin of National Mining University . Issue 2, 130-135.

(2018). http://nvngu.in.ua/jdownloads/pdf/2018/02/NVNGU $02 \quad 2018$ Tulchynska.pdf.

14. A.V. Oyvental. Implementation of personnel strategy of the organization. Problems of management theory and practice. №4. P. 61- 63. (2017)

15. E.P. Parkhimchik. Personnel policy of the organization: [textbook. Aid.]. Minsk: GIUST BSU, 128 p. (2011)

16. M. Radovic, A. Salamzadeh The Importance of Communication in Business Management Researchgate.net

17. T.S. Udovenko, C.M. Nevmerzhytska Formation of effective personnel policy at the enterprise [Electronic resource]. Access mode: http://knutd.com.ua/publications/pdf/Ukrainian_editi ons/ Nevmerzicka2015022807.pdf

18. V.D. Yakubenko. Participatory management in the socialization of corporate relations. Scientific Bulletin of the Chernivtsi Trade and Economic Institute KNTEU: Coll. Science. wash. Vip. IV. Chernivtsi. P. 19-24. (2003). 